\title{
Türk Kütüphanecilik Tarihinde Hasan Fehmi Edhem Karatay ve Yayımlanmamış Bir Belge
}

\section{Hasan Fehmi Edhem Karatay and an Unpublished Document in the History of Turkish Librarianship}

\author{
Ayşe Buluş $^{*}$ ve Burak Delibaş ${ }^{* *}$
}

$\ddot{O}_{z}$

Bu çalışmada Türk kütüphanecilik tarihinde önemli bir yere sahip olan Hasan Fehmi Edhem Karatay'ın kütüphanecilikle olan ilişkisi kronolojik sırayla aktarılmış ve daha önce yayımlanmamış yeni bir belgenin tanıtılması amaçlanmıştır.

Anahtar Kelimeler: Türk kütüphaneciliği; kütüphanecilik tarihi; kütüphanecilik eğitimi

\begin{abstract}
In this study, the relationship between librarianship and Hasan Fehmi Edhem Karatay, who has an important place in the history of Turkish librarianship, is explained in chronological order and a new document that has not been published before is aimed to be introduced.
\end{abstract}

Keywords: Turkish librarianship; history of librarianship in Turkey; education of librarianship

\section{Giriş}

Hasan Fehmi Edhem Karatay, Türk kütüphaneciliği için önemli isimlerden birisidir. Kısaca Karatay, modern kütüphaneciliğin Türkiye'deki ilk temsilcisi, yurtdışında eğitim alan ilk kütüphaneci, ilk meslek kursunu açan, fiş katalog sistemini ve onlu sınıflamayı uygulayan, bibliyografik çalışmalar yapan, kütüphanecilik alanında ilk meslek kitabını neşreden önemli bir araştırmacı ve eğitmendir. Biyografisi ve yapmış olduğu görevler literatürdeki kaynaklarda çalışmanın amacına göre farklı bakış açılarıyla ele alınmıştır. Ancak bu kaynaklardaki kronolojik akış incelendiğinde bazı tarih farklılıkları dikkat çekmektedir. Bu çalışmada Karatay'ın kütüphane ve kütüphanecilikle olan ilişkisi tarihsel çizgide incelenmiştir. Ayrıca Maarif Vekaleti tarafından Karatay'a gönderildiği tespit edilen ve daha önce yayımlanmamış olan bir belgenin tanıtımı yapılmıştır.

\footnotetext{
* Doktora Öğrencisi, Marmara Üniversitesi, Bilgi ve Belge Yönetimi Bölümü. E-posta: aysebulus@marun.edu.tr PhD Student, Marmara University, Department of Information and Records Management, Turkey.

${ }^{* *}$ M.A., İstanbul Sağlık ve Teknoloji Üniversitesi, Kütüphane ve Dokümantasyon Daire Başkanlığı E-posta: burak.delibas@istun.edu.tr M.A., Istanbul Health and Technology University, Department of Library and Documentation, Turkey.
} 


\section{Hasan Fehmi Edhem Karatay}

Hasan Fehmi Edhem Karatay (5 Ekim 1888 - 20 Ocak 1968), 1924 yılında Dârülfünun Edebiyat Fakültesi Kütüphanesi'nde görevlendirilmesiyle kütüphanecilik mesleğine ilk adımını atmıştır ${ }^{1}$ (Eyice, 1995). Kütüphanecilik tahsili için Dârülfünun tarafindan Ekim 1924'te Paris'e gönderilmiştir. ${ }^{2}$ Paris’te Fransız "Ecole des Chartes” adlı arşivci ve kütüphaneci yetiştirilen okula başlamıştır. Okulun daha çok arşivci yetiştirmesi üzerine buradan ayrılarak, Paris’te Amerikalılar tarafından açılmış olan "Ecole des Bibliothecaires” te kütüphanecilik eğitimine katılmıştır (Karatay, 1968; Subaşığlu ve Tamdoğan, 2014; Stummvoll, 1962). Burada matbaacılık, paleografya, tarih gibi dersler görmüş, bununla beraber Milli Kütüphane'de uygulama yapma imkânı elde ederek bu okuldan başarıyla mezun olmuştur. 21 Temmuz 1925 tarihli İkdam, Cumhuriyet ve Vatan gazetelerine vermiş olduğu röportajlar ${ }^{3}$, Karatay’ın İstanbul'a bu tarihten önce dönmüş olduğunu göstermektedir (Şenalp, 2001; Dârülfünun'un Zengin ve Büyük Kütüphanesi, 1925; Dârülfünun Kütüphanesinde Islahat, 1925; Dârülfünun Kütüphanesi, 1925).

İstanbul'a dönmesinden kısa bir zaman sonra Dârülfünun Kütüphanesi'ne müdür olarak tayin edilmiş ve 15 Ağustos 1925 tarihinde göreve başlamıştır (Candemir, 2007). Şenalp tarafından yayımlanan 1925(?) tarihli bir belgeden bu tarihlerde Sabri ${ }^{4}$ Bey'in müdür vekilliği yaptığı anlaşılmaktadır (Şenalp, 2001). Karatay'ın müdürlük vazifesiyle birlikte dört memur ve biraz Almanca ve Fransızca bilen personel ${ }^{5}$ ile ilk önce Edebiyat Fakültesi Kütüphanesi'nin tasnif ve katalogları tamamlanmış, daha sonra da aynı işlemler hukuk, fen, ilahiyat kütüphanelerindeki kitaplar için yapılmıştır. ${ }^{6}$ Basma kitapların tasnifi bittikten sonra hızlı bir şekilde yazma eserlerin fiş katalogları hazırlanmıştır. Böylece bütün kitapların fiş katalogları hazırlanarak kartoteks oluşturulmuştur. Bu süreçte yaklaşık 140.000 kitabın 15 yılda tamamlandığı nakledilmiştir (Şenalp, 2001).

\footnotetext{
${ }^{1}$ Bu tarihte Dârülfünun Kütüphanesi koleksiyonu İsmail Hakkı Baltacıoğlu'nun girişimleri ve Maarif Vekaleti'nin buyruğuyla bağış ve satın alma yoluyla oluşturulmuş. Koleksiyon; Rıza Paşa, Halis Efendi, Mollazâde İbrahim Bey'den satın alınan kitaplar, İttihat ve Terakki kitapları, Hakkı Paşa'nın 3.998 kitabı, Şevki Paşa'nın üniversiteye bağışladığı kitaplar ve İbnülemin Mahmut Kemal İnal'ın bağışladığı 4.000 yazma ve eski harfli basma kitaplardan oluşmaktadır. 1925 yılında 7.000 yazma, 1.500 eski harfli basma, 1.800 albüm ve haritadan oluşan Yıldız Sarayı Kitaplığı Koleksiyonu Dârülfünun Kütüphanesi’ne taşınmıştır (Tüfekçibaşı, 1997; Karatepe, 2013). 1926-1927 devlet sâlnâmesine göre bu tarihlerde İstanbul Darülfünun Kütüphanesi'nde kayda geçmiş 88.530 basma, 17.817 yazma eser olmak üzere toplam 106.347 yayın bulunmaktadır (Candemir, 2004, s. 373). Y1ldız Saray1 Kütüphanesi'nin Dârülfünun'a devredilmesiyle birlikte, Yıldız Sarayı Kütüphanesi hâfız-1 kütübü Sabri Kalkandelen bu koleksiyondan sorumlu olarak görevine Dârülfünun'da devam etmiştir (Dölen, 2010, s. 302). Hasan Fehmi Edhem Karatay'ın Kütüphanecilik eğimi için Ekim 1924'te Paris'e gönderilmesiyle birlikte Kalkandelen Dârülfünun Kütüphanesi Müdür Vekilliğine atanmıştır (Candemir, 2007).

${ }^{2}$ Türk Kütüphaneciler Derneği Bülteni'nde yayımlanan Hasan Fehmi Edhem Karatay'ın evrakları arasından çıkan "Hayatımdan Parçalar" adlı yazıda Ekim 1925 yılında Paris'e gönderildiği ve bir yıl kadar eğitim aldığı nakledilmiştir. Ancak 15 Eylül 1925 yılında gerçekleşen kütüphanecilik kursu ve kütüphanedeki yazışma dosyalarından hareketle 1924 Ekim'inde gittiği düşünülmüsstür (Şenalp, 2001, s. 16).

${ }^{3}$ Yurtdışında kütüphanecilik eğitimini tamamlayarak yurda dönen Karatay'ın aynı tarihte üç farklı gazeteye röportaj vermesi, bir kütüphane müdürünün yurda dönüşünün basın tarafindan takip edildiği ve Dârülfünun Kütüphanesi’nde yapılacak yeniliklere verilen önemin bir göstergesi olarak değerlendirilebilir.

${ }^{4}$ Şenalp tarafından sehven Hayri Bey yazılmıştır. Bu kişi Sabri Kalkandelen'dir. Bu konuya dikkat çeken İBB

Kütüphane ve Müzeler Müdürlüğü, Nadir Eser Uzmanı Hüseyin Türkmen'e çok teşekkür ederiz.

${ }^{5}$ Bu memurlar Hukuk kısmına bakan Yervant Damgaciyan, Fen kısmına bakan Salih Efendi, Edebiyat kısmına bakan Ahmet Caferoğlu ve Ferit Beylerdir (Karatay, 1968; Şenalp, 2001; Yazıbakan, 2019).

${ }^{6}$ 1923-1930 yılları Dârülfünun Umûmî Kütüphanesi, Tıp, Edebiyat ve Hukuk Fakültesi Kütüphanelerine ait fotoğraflar için bkz. (Dölen, 2010, s. 292-295, 301; Karatay, 1946, s. 19-20).
} 
Hasan Fehmi Edhem Karatay 15 Eylül 1925 y1lında Türkiye'de ilk kütüphanecilik kursunu açmış ve devamında "Kütüphanecilik" ", "Kitabiyat ${ }^{8}$ " ve "Tasnif-i âşarî kavâidi meslek kitaplarını hazırlamıştır. 1926 yılında "İstanbul Dârülfünun Kütübhanesi Talimatnâmesi"ni hazırlamış ${ }^{10}$ ve Fransa'da 1925 yılında yürürlüğe giren derleme yasası “Dépot Légal Obligatoire”yı tercüme etmiştir (Üstün, 1977; Candemir, 2007; Acaroğlu, 1953). Aynı yıl “Kütüphanecilik Okulu” kurmak üzere Maarif Vekâleti'ne önerilerini sunmuş ancak sonuç alamamıştır (Şenalp, 2001). 1937 yılında ise Arkeoloji Müzesi Eski Eserleri Koruma Encümeni âzalığına seçilmiştir (TK Yayın Kurulu, 1952). 1940 yılında yayımlanan Eski Eserleri Koruma Encümeni 1939 yılı mesaî raporunda ve İstanbul Arkeoloji Müzeleri Müdürlüğü tarafından İstanbul anıtları hakkında alınan kararda azalığının devam ettiği görülmektedir (1939 Yılı Mesaî Raporu, 1940; İstanbul Anıtları Hakkında, 1945). 1941 yılında "Alfabetik Katalog Kaideleri” adlı eseri, 1946 yılında Türkiye Turing ve Otomobil Kurumu Belleteni'nde “İbrâhim Paşa Camisi ve Üniversite Kitaplığı” ve "Ragıp Paşa Kütüphanesi” adlı yazıları yayımlamıştır (Karatay, 1946; Karatay, 1946b). 15 Kasım 1949 tarihli Cumhuriyet Gazetesi'ndeki bir habere göre UNESCO Türkiye Milli Komisyon Kurulu içerisindeki "Müzecilik ve Kütübhanecilik Kurulu”na Fehmi Edhem Karatay seçilmiştir (Unesco Türkiye Millî Komisyonu Toplantısı, 1949). 1950 tarihinde İstanbulun Beşyüzüncü ve Müteakip Fetih Yıllarını Kutlama Derneği ana nizamnamesine göre Üniversite Kütüphanesi Müdürü sıfatıyla derneğin kurucu üyeleri arasında yer almıştır (Ana Nizamname, 1950). Buna ek olarak 1951 yılında gerçekleşen İstanbulun Beşyüzüncü ve Müteakip Fetih Yıllarını Kutlama Derneği ikinci genel toplantısında belirtilen kararla Fehmi Edhem Bey'in "Fatih Devri Bibliyografyası" hazırlayacağı belirtilmiştir (İkinci Genel Kurul, 1951). Bir gazete kupüründen öğrendiğimize göre Karatay, İstanbul Fetih Cemiyeti'nin yayın organı olan İstanbul Enstitüsü âzâlığını da yapmıştır (Yahyâ Kemal Enstitüsü, t.y.).

Karatay, 3 Ekim 1953 y1lında İstanbul Üniversitesi Kütüphanesi’nden emekliye ayrılmıştır. ${ }^{11}$ Daha sonra Halûk Şehsuvaroğlu'nun davetiyle 23 Mayıs 1957-31 Mayıs 1967 tarihleri arasında Topkapı Sarayı Kütüphanelerinin tasnifi, yazmaların kataloglarının telif ve tertibi için çalışmaya başlamıştır (TK Yayın Kurulu, 1968). Prof. Albert Gabriel tarafından hazırlanan "Chateaux turcs du Bosphore" adlı eserin "Rumeli Hisarı" bölümünü çevirerek 1959 yılında İstanbul Enstitüsü Mecmuası'nda yayımlamıştır. ${ }^{12} 1961$ yılında iki cilt olarak Türkçe, bir cilt olarak Farsça yazmalar katalogları, 1962 yılında Arapça yazmalar kataloğunun birinci, 1964 yılında da Arapça yazmalar kataloğunun ikinci ciltleri yayımlanmıştır. Akabinde üçüncü ve dördüncü ciltlerin müsveddeleri tamamlanmıştır ${ }^{13}$ (Karatay, 1968). 1963 yılında Prof. Albert

\footnotetext{
${ }^{7}$ Fehmi Edhem (1341). Kütüphanecilik. İstanbul: Dârülfünun Matbaası. Bu kitabın birinci bölümü "Kütüphane Tarifi, Menşe'ı Hülâsa-i Tarihiyesi” başlığıyla Fehmi Edhem tarafından yeni harflerle de yayımlanmıştır (Karatay, 1968). "Yazma Eserlerin Kataloglanması" bölümü ise İsmail E. Erünsal tarafından Kütüphanecilikle ilgili Osmanlıca metinler ve belgeler I adlı kitapta yayımlanmıştır (Erünsal, 1982).

${ }^{8}$ Fehmi Edhem (1341). Kitabiyat. İstanbul: Dârülfünun Matbaası. Bu kitabın 59-61. sayfaları "Kitabiyat" başlı̆̆ ile İsmail E. Erünsal tarafından yayımlanmıştır (Erünsal, 1982).

${ }^{9}$ Fehmi Edhem (1341). Tasnif-i âşarî kavâidi. İstanbul: Dârülfünun Matbaası.

10 İstanbul Dârülfünun Kütüphanesi Talimatnamesi. (1926). İstanbul: Türkiye Cumhuriyeti İstanbul Darülfünunu.

${ }^{11}$ Karatay’ın emekliye ayrılması ile daha önce kütüphane müdür vekilliği yapan Sabri Kalkandelen'in oğlu Nurettin Kalkandelen kütüphane müdürlügüne tayin edilmiştir (Şehsuvaroğlu, 1975).

12 Istanbul Enstitüsü Mecmuası V, 1959, s. 101-131.

${ }^{13}$ Dr. Müjgân Cunbur ve Prof. Dr. Semavi Eyice tarafından verilen eser künyeleri için bakınız (Cunbur, 1968, s. 6-7; Eyice, 2001, s. 474). Karatay'ın eserleri arasında yer alan "Les manuscrits orientaux illustrés de la
} 
Gabriel tarafindan yazılan ve R. Ekrem Koçu İstanbul Ansiklopedisi VI. cildinde yayımlanan "Boğaz Kesen Kalesi - Rumeli Hisarı” adlı yazıyı Türkçe’ye çevirmiştir.

20 Ocak 1968 tarihinde vefat eden Karatay, Edirnekapı'da Sakızağacı şehitliği birinci ada 97 numaralı kabre defnedilmiştir (Cunbur, 1968). Vefatının ardından çeşitli etkinliklerle anılmaya devam etmiştir. 25 Ocak 1983 tarihinde Türk Kütüphaneciler Derneği, Milli Kütüphane'de "Fehmi Ethem Karatay ve Aziz Berker" için anma toplantısı düzenlemiştir (Anma Toplantısl, 1983). 27 Mart 1995 tarihinde 31. Kütüphane Haftası etkinlikleri arasında “İstanbul Üniversitesi Nadir Eserler ve Müze Kütüphanesi Okuma Salonu'na Fehmi Ethem Karatay adının verilmesi töreni” gerçekleştirilmiştir (XXXI Kütüphane Haftası Kutlama Programı, 1995; [31. Kütüphane Haftası Davetiyesi], 1995). 10-12 May1s 2018 tarihleri arasında düzenlenen III. Uluslararası Bilgi ve Belge Yönetimi Bölümü Öğrenci Kongresi’nde "Fehmi Ethem Karatay’a Saygı Oturumu” gerçekleştirilmiştir.

\section{Kütüphanecilik Kursu}

Kütüphanecilik kursu 15 Eylül 1925 yılında başlamış ve 1926 Mayıs başlarında sona ermiştir. Kurs bitiminden bir hafta sonra sınav yapılmış ve başarılı olan kütüphanecilere birer ehliyetname verilmiştir. Subaşığlu ve Tamdoğan, bu kursu bitirenlere verilen ehliyetnamenin resmini ve yeni harflere çevrilmiş halini çalışmalarında yayımlamışlardır (Subaşıoglu ve Tamdoğan, 2014). Süleymaniye Kütüphanesi Mikrofilm Arşivi 02703 numarada kayıtlı "Kütüphanecilik Kursu Ehliyetnamesi”nin görüntüsü net ve tam olmadığı için, Subaşı ve Tamdoğan'ın yayımlamış oldukları ehliyetnamenin bir başka örneği mi, ehliyetnamenin eki mi, farklı bir ehliyetname mi olduğu ne yazık ki anlaşılamamıştır. Temin edilen görüntü Abdullah Zihni Efendi'ye ait bir tezkere örneğini andırmaktadır. Her iki ehliyetname örneğinin de kaynağına ulaşılamaması bu soruların cevapsız kalmasına neden olmuştur. ${ }^{14}$

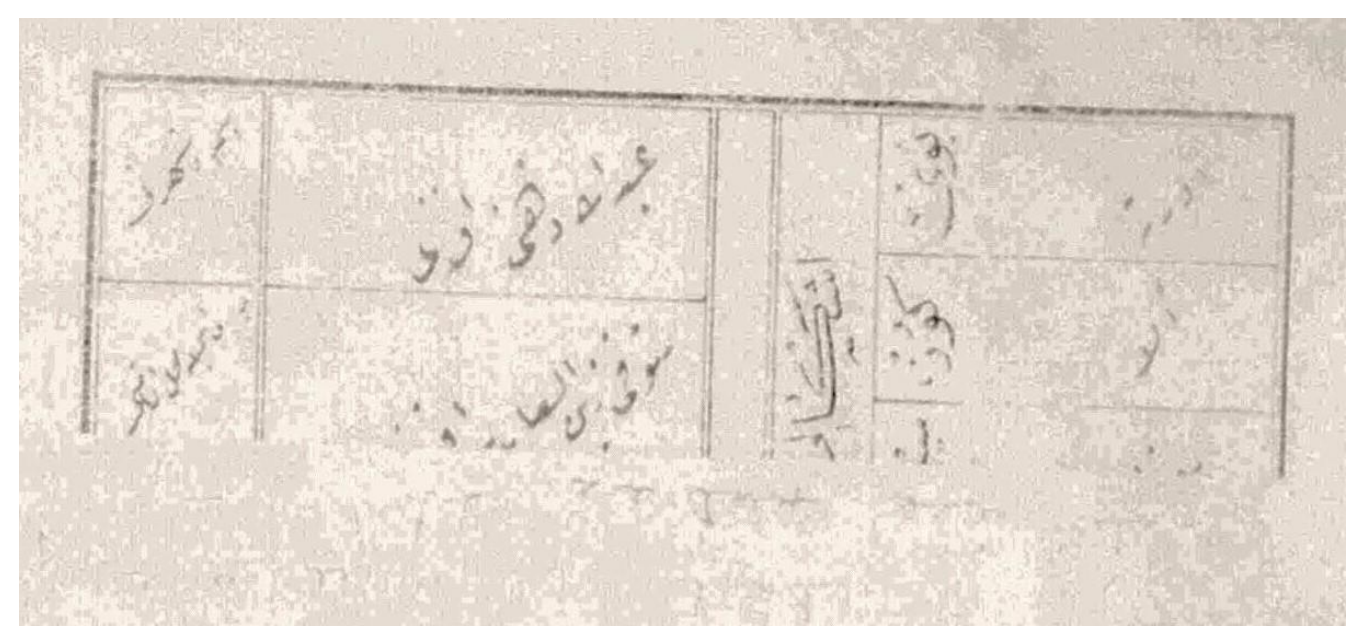

Şekil 1. Süleymaniye Kütüphanesi Mikrofilm Arşivi’ndeki Kütüphanecilik Kursu Ehliyetnamesi

\footnotetext{
Bibliothèque del'Université de Stamboul" isimli eserin bir müzayedede bir milyon yedi yüz bin liraya satıldığını bir gazete haberinden öğrenmekteyiz (Sahaflar, bibliyomanlar ve yuppiler, t.y.).

${ }^{14}$ Türkiye Yazma Eserler Kurumu Başkanlığı Süleymaniye Yazma Eser Kütüphanesi Mikrofilm Arşivi’nde bulunan ehliyetname örneği net ve tam olmadığından, ehliyetnamenin orijinal kaynağının tespiti için kütüphaneye resmî başvuru yapılmıştır. Yapılan bu başvuruya çok kısa bir zaman içerisinde cevap verilerek, belgenin aslının Süleymaniye Kütüphanesi'nde olmadığı ve mikrofilmin satın alma veya bağışçıına ait herhangi bir kaydın da bulunmadığı bilgisi verilmiştir.
} 
İdare, katalog ve diğer kütüphanecilik derslerinin verildiği bu kursa 30 kadar kütüphaneci ${ }^{15}$ katılmıştır (Artukoğlu, 1962). 14 Teşrinievvel 1341 / 14 Ekim 1925 tarihli belgeden öğrenildiğine göre, harcırah olmayışından dolayı taşra hâfız-1 kütübleri kursa katılamamış yalnızca İstanbul'daki hâfız-1 kütübler katılabilmiştir. Ama kurs talimatnamesi, programı ve ders notlarının ilk formaları taşra hâfız-1 kütüblerine gönderilmiştir (Ersoy, 1962). Adnan Ötüken, Fehmi Edhem tarafından kendisine gönderilen kurs talimatnamesi ve müfredatının tercümesini 1957 yılında, İsmail E. Erünsal ise kurs müfredatını eski harflerle 1982 yılında yayımlamıştır ${ }^{16}$ (Ötüken, 1957; Erünsal, 1982).

\title{
Kütüphaneciler Kursu Talimatnamesi
}

1- 1341 senesi eylülünün 15 inde İstanbul'da İstanbul Lisesine merbut olarak Süleymaniye Medresesinde kütüphanecilik kursu açılması mukarrerdir. ${ }^{17}$

2- Darülfünun Kütüphanesi Müdürü Fehmi Edhem Bey dersleri takrir edecek ve Kütüphaneler Müfettişi Ahmed Tevhid Bey (Şark Bibliyografisi) ile (eski yazlların kıraati) hakkında konferanslar verecektir.

3- Ders pazartesi, çarşamba ve cumartesi günleri saat ondan onbire kadardır.

4- Bugünkü gün hizmette bulunan kütüphane müdürleri ile hâflzı kütüplerin cümlesi bu derse devama mecburdur.

5- Lâakal orta mektep tahsilini ikmal etmiş olanlardan kütüphanecilik mesleğini arzu edenler bu kursa iştirak edebilirler.

6- Nisan gayesine kadar devam edecek bu derslerden müdavimler imtihan edilir. Ehliyet tebeyyün edenlere birer ehliyetname verilir.

7- Hidemat-l sabıkalara hürmeten müstahak-ı tekaüt oldukları halde hizmetlerinde alıkonulmuş olan müsin zevatın derse devam hususu ihtiyarlarina birakılır

$H \hat{A} M I D D Z \ddot{U B E Y R}$

\author{
22 A $\breve{g u s t o s} 1341$ \\ Maarif Vekili namına \\ NAFI ATUF
}

Şenalp tarafından yayımlanan 17 Ağustos 1341 / 17 Ağustos 1925 tarihli bir diğer belgeden anlaşıldığı üzere 9 A ğustos 1341 / 9 A ğustos 1925 tarihinde "Kütüphanecilik Kurslarının" gerçekleştirileceği başvekillik emiriyle kararlaştırılmıştır. Yine bu belgeye göre kurs programı hazırlanarak Maarif Vekaleti'ne gönderilmiştir (Şenalp, 2001). 17 Ağustos 1925

\footnotetext{
${ }^{15}$ Adnan Ötüken, “Türkiyede Kütüphanecilik Öğretiminin Tarihçesi” adlı yazısında kursa katılan kişilerin kimler olduğunu bilen veya hatırlayan meslektaşlarına çağrı yaparak, kendisi ile paylaşılmasından minnet duyacağını ifade etmiştir (Ötüken, 1957). Ötüken'in bu çağrısına cevap veren meslektaşlarının olup olmadığı bilinmiyor ama bu önemli kursa katılan kişilerin peşine düşülmesi gerektiğine inanıyoruz.

${ }^{16} 1$ Eylül 1925, Maarif Haberleri (Kütüphanecilik Kursu - Talimatname), Maarif Vekaleti Mecmuasl, 1 (5), 104107.

${ }_{17}$ Artukoğlu, kursun Süleymaniye Medresesi’nde İstanbul Lisesi’ne bağlı olarak gerçekleştiğini belirtmiştir (Artukoğlu, 1962, s. 5).
} 
tarihli belgeyle Maarif Vekaleti’ne gönderilen kurs programı ve talimatname 22 Ağustos 1925 tarihinde basılmıştır.

Düzenlenen bu kursa dair bir başka belge ise, 5 Eylül 1341 / 5 Eylül 1925 tarihinde İstanbul Maarif Müdürü Reşid Bey tarafından Fehmi Edhem Karatay’a gönderilmiştir. ${ }^{18} \mathrm{Bu}$ belgede, kursa ilişkin bütün hazırlık süreçleri özetlenerek Hars Müdüriyeti'nden bu konuda bilgi geldiği ve Süleymaniye'de derslere devam edileceği belirtilmiştir.

Fehmi Edhem Bey'in 21 Temmuz 1925 tarihinden kısa bir süre önce İstanbul'a geldiği, Dârülfünun Kütüphanesi'ne müdür tayin edilerek 15 Ağustos 1925 tarihinde göreve başladığ ve 15 Eylül 1341 / 15 Eylül 1925 tarihinde kütüphanecilik kursunun başladığı düşünüldüğünde, sürecin çok hızlı planlandığı ve gerçekleştirildiği anlaşılmaktadır.

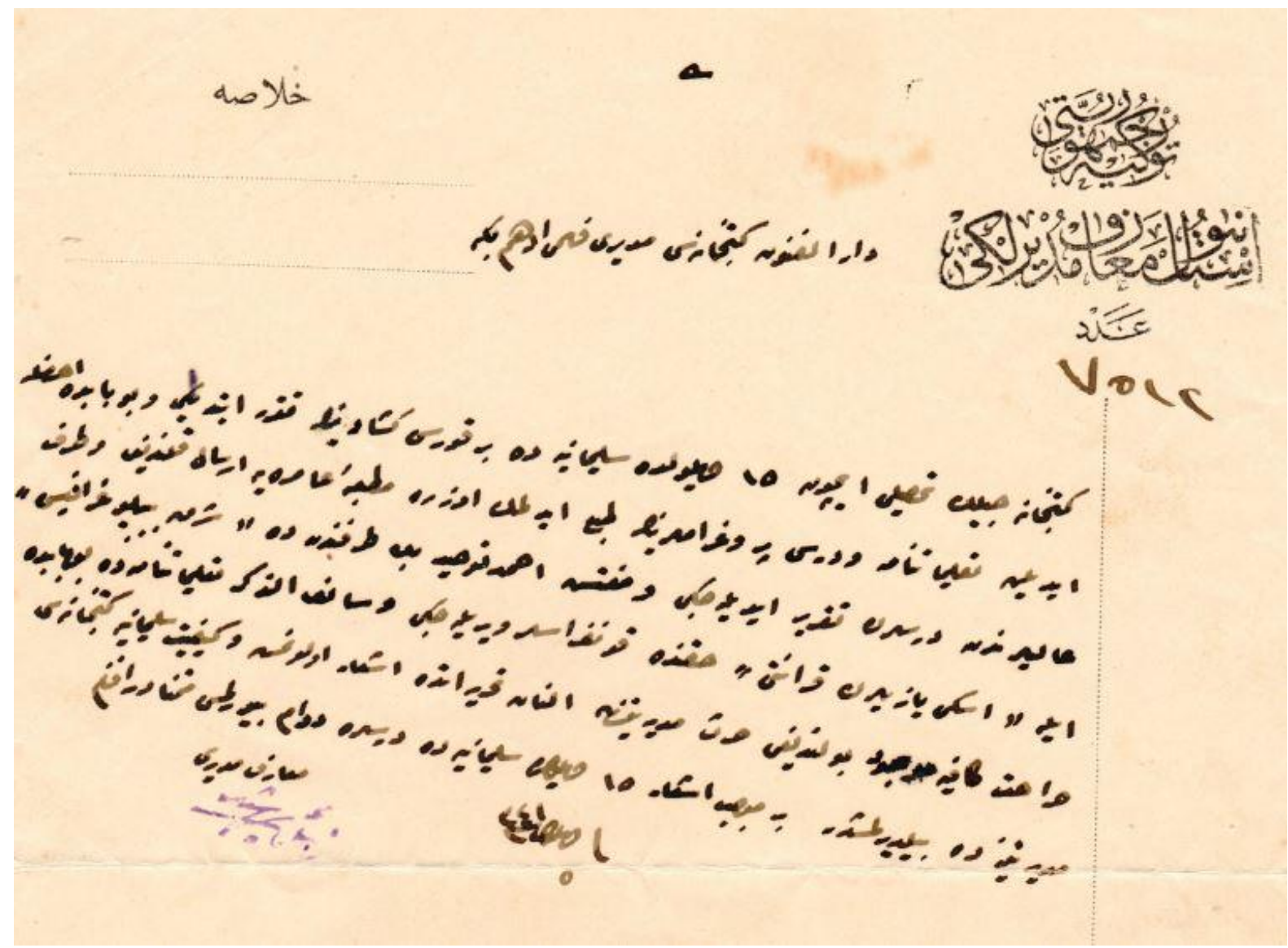

Şekil 2. Türkiye Cumhuriyeti İstanbul Maarif Müdürlüğü’nün Fehmi Edhem Bey’e gönderdiği belge

Türkiye Cumhuriyeti Istanbul Maarif Müdürlüğ̈̈

Aded 7512

Dârülfünun Kütübhanesi Müdürü Fehmi Edhem Bey'e

Kütüphanecilik tahsili için 15 Eylül'de Süleymaniye'de bir kurs küşadının takarrür ettiği ve bu bâbda ihzâr[?] edilmiş talimatnâme ve ders programlarının tab' edilmek üzere Matbaa-i Amire'ye irsal kılındiğ ve taraf-ı âlilerinden derslerin takrir edileceği ve müfettiş Ahmed

\footnotetext{
${ }^{18}$ Belge Burak Delibaş'ın özel arşivindedir.
} 
Tevhid Bey tarafindan da "Şark Bibliyografisi" ile "Eski Yazllartn Kiraatı" hakkında konferanslar verileceği ve sâlifü'z-zikr talimatnâmede bu bâbda hırâset kâffeye mevcud bulunduğu Hars Müdüriyeti'nden alınan tahriratta iş'âr olunmuş ve keyfiyet Süleymaniye Kütüphanesi Müdüriyeti'ne de bildirilmiştir Ber mucib-i iş'âr 15 Eylül'de Süleymaniye'de derslere devam buyrulması mütemennâdır efen[d]im.

Fî 5 Eylül Sene [1]341 [5 Eylül 1925]

Maarif Müdürü

[Reşid Bey]

\section{Sonuç}

Tanzimat Fermanı'nın ilanından sonra vakıf kütüphanelerine ilişkin görev ve sorumlulukların Evkaf Nezâreti ile Maarif Nezâreti arasında paylaşılması, kütüphanelerin işleyişi ve yönetilmesi bakımından problemler doğurmuştur. Cumhuriyet'in ilanından kısa bir süre sonra 3 Mart 1924 'te çıartılan Tevhid-i Tedrisat Kanunu ile Şer'iye ve Evkaf Vekaleti veya hususi vakıflar tarafindan idare edilen bütün medrese ve mekteplerin Maarif Vekaleti'ne devredilmesiyle, kütüphanelerin işleyiş ve yönetim karmaşasına bir yenisi daha eklenmiş̧ir.

Tevhid-i Tedrisat Kanunu kapsamında medreselerin kapatılmasıyla Medresetü'l-Kudât kütüphane olarak kullanılmak üzere Dârülfünun’a devredilmiştir. Bu sırada Dârülfünun Kütüphanesi'nde görevlendirilen Hasan Fehmi Edhem Karatay Maarif Vekaleti tarafindan kütüphanecilik eğitimi almak üzere Paris'e gönderilmiş, ülkeye döndüğünde ise edindiği tecrübelerini meslektaşlarına aktarmak için bir kütüphanecilik kursu açılması talebinde bulunmuştur.

Kütüphanelerin idari teşkilatının hâlâ tam oturmamış olduğu bir dönemde Hars Dairesi ve bağlı olduğu Maarif Vekaleti'nden gerekli izinler alınarak kütüphanecilik kursu açılmıştır. Dönemin bütün şartları değerlendirildiğinde derslerin büyük kısmını tek başına üstlenen Fehmi Bey'in fazlasıyla yenilikçi ve ilerici düşüncelerinin müfredat programına yansıdığı ve kursun dikkatlice programlandığı görülmektedir. Ayrıca, ders notlarının taşbaskısının yapılması da ilk kütüphanecilik meslek kitabının yayımlanmış olması açısından fazlasıyla önem teşkil etmektedir.

Hasan Fehmi Edhem Karatay modern Türk kütüphaneciliği yolunda ilk adımları atarak birçok ilki gerçekleştirmiştir. Yurtdışındaki eğitimini tamamladıktan çok kısa bir süre sonra kütüphanecilik kursunu planlamış ve hayata geçirmiş, Türk kütüphaneciliğine dair birçok çalışma yayımlamıştır. Karatay gibi Türk kütüphaneciliğine hizmet etmiş kişilerin daha farklı çalışmalarla ele alınarak kütüphanecilik mesleğimizin yeni çalışmalarına ilham vermesi temenni edilmektedir. Mesleğimiz ve tarihimiz açısından 53. vefat yıl dönümünün tamamlandığı bugünlerde Hasan Fehmi Edhem Bey'i hayranlık, minnet, rahmet ve saygıyla aniyoruz. 


\section{Kaynakça}

(1949, 15 Kasım). Unesco Türkiye Millî Komisyonu Toplantısı. Cumhuriyet, s. 33.

[31. Kütüphane Haftası Davetiyesi]. (1995). [Davetiye]. Taha Toros Arşivi (Envanter No: 001610202016), İstanbul Şehir Üniversitesi e-Arşiv Sistemi. Erişim adresi: http://earsiv.sehir.edu.tr:8080/xmlui/bitstream/handle/11498/13785/001610202016.pdf?seque ce $=1 \&$ is Allowed $=y$

1 Eylül 1925, Maarif Haberleri (Kütüphanecilik Kursu - Talimatname), Maarif Vekaleti Mecmuası, 1 (5), 104-107. Erişim adresi: https://dijital kutuphane.mkutup.gov.tr/tr/periodicals/articlecatalog/details/28704

Acaroğlu, M. T. (1953). Basma Yazı ve Resimleri Derleme Kanunumuz. Türk Kütüphaneciler Derneği Bülteni, 2 (2), 125-138. Erişim adresi: http://www.tk.org.tr/index.php/TK/article/view/2261/2227

Artukoğlu, A. (1962). Türkiyede Kütüphanecilik Eğitimi. Kütüphaneciliğin Sesi, 1 (2-3), 5-10.

Banarlı, Nihad Sami. Edebi Sohbetler: Yahyâ Kemal Enstitüsü. [Gazete Kupürü]. Taha Toros Arşivi (Envanter No: 001506479006), İstanbul Şehir Üniversitesi e-Arşiv Sistemi. Erişim adresi: http://earsiv.sehir.edu.tr:8080/xmlui/handle/11498/8355

Candemir, M. (2004). Cumhuriyetin Başlangıcında Kaleme Alınan İstanbul Darülfünunu Kütüphanesi'ne Ait Bir Dahilî Nizâmnâme Lâyihası. Türk Kütüphaneciliği, 18 (4): 363-384. Erişim adresi: http://www.tk.org.tr/index.php/TK/article/view/211/206

Candemir, M. (2007). Yıldız Sarayı Kütüphanesi: Saray'dan Üniversite’ye. Tarih Dergisi, 45, 123 153.

Cunbur, M. (1968). Fehmi Ethem Karatay. Türk Kütüphaneciler Derneği Bülteni, 17 (1), 3-7. Erişim adresi: http://www.tk.org.tr/index.php/TK/article/view/1814/1794

Dârülfünun Kütüphanesi (1925, 21 Temmuz). [Gazete kupürü, Vatan]. İ.B.B. Atatürk Kitaplığı Sayısal Arşiv ve e-Kaynaklar (Envanter No: NS2349), İ.B.B Atatürk Kitaplığı, İstanbul.

Dârülfünun Kütüphanesinde 1slahat (1925, 21 Temmuz). [Gazete kupürü, Cumhuriyet]. İ.B.B. Atatürk Kitaplığı Sayısal Arşiv ve e-Kaynaklar (Envanter No: NS0336), İ.B.B Atatürk Kitaplığı, İstanbul.

Dârülfünun'un zengin ve büyük kütüphanesi ilmî ve asrî bir surette tasnif edilmeye başlandı $(1925,21$ Temmuz). [Gazete kupürü, İkdam]. İ.B.B. Atatürk Kitaplığı Sayısal Arşiv ve e-Kaynaklar (Envanter No: NS0907), İ.B.B Atatürk Kitaplı̆̆

Dölen, E. (2010). Türkiye Üniversite Tarihi 2: Cumhuriyet Döneminde Darülfünun (1922-1933). İstanbul: İstanbul Bilgi Üniversitesi Yayınları.

Ersoy, O. (1962). Kütüphaneciliğimizle İlgili Belgeler. Türk Kütüphaneciler Derneği Bülteni, 11 (1 2): 22-28. Erişim adresi: http://www.tk.org.tr/index.php/TK/article/view/2042/2011

Erünsal, İ. E. (1982). Kütüphanecilikle ilgili Osmanlıca metinler ve belgeler I. İstanbul: İstanbul Üniversitesi Edebiyat Fakültesi Yayınları.

Eski Eserleri Koruma Encümeni 1936 Y1lı Mesaî Raporu. (1940). İstanbul: Riza Koşkun Matbaası.

Eyice, S. (1995). İstanbul Üniversitesi Edebiyat Fakültesi Kütüphanesi Tarihçesine Dair. İstanbul Üniversitesi Sosyoloji Dergisi, 3 (4), 1-8. Erişim adresi: https://dergipark.org.tr/tr/pub/iusosyoloji/issue/530/4838

Eyice, S. (2001). "Karatay, Fehmi Ethem", TDV İslam Ansiklopedisi, 24, 473-474.

İstanbul Anıtları Hakkında Alınan Karar. (1945). [Karar Belgesi]. Aziz Ogan Koleksiyonu (Envanter No: OGNIST0101506), Boğaziçi Üniversitesi Arşiv ve Dokümantasyon Merkezi. Erişim adresi: 
http://digitalarchive.boun.edu.tr/bitstream/handle/123456789/3293/OGNIST0101506.pdf?seq ence $=1 \&$ isAllowed $=\mathrm{y}$

İstanbul Dârülfünun Kütüphanesi Talimatnamesi. (1926). İstanbul: Türkiye Cumhuriyeti İstanbul Darülfünunu.

İstanbulun Beşyüzüncü ve Müteakip Fetih Yıllarını Kutlama Derneği Ana Nizamnamesi. (1950). İstanbul: İstanbulun Beşyüzüncü ve Müteakip Fetih Yıllarını Kutlama Derneği.

İstanbulun Beşyüzüncü ve Müteakip Fetih Yıllarını Kutlama Derneği İkinci Genel Toplantısı 1951. (1951). İstanbul: İstanbulun Beşyüzüncü ve Müteakip Fetih Yıllarını Kutlama Derneği, Sucuoğlu Matbaası.

[Karatay], F. E. (1341). Kitabiyat. İstanbul: Dârülfünun Matbaası.

[Karatay], F. E. (1341). Kütüphanecilik. İstanbul: Dârülfünun Matbaas1.

[Karatay], F. E. (1341). Tasnif-i Âşarî Kavaidi. İstanbul: Dârülfünun Matbaası.

Karatay, F. (1946). İbrâhim Paşa Camisi ve Üniversite Kitaplı̆̆. Türkiye Turing ve Otomobil Kurumu Belleteni, 73, 17-21.

Karatay, F. (1946). Ragıp Paşa Kütüphanesi. Türkiye Turing ve Otomobil Kurumu Belleteni, 59, 21 22.

Karatay, F. E. (1968). Kütüphane Tarifi, Menşe'1 Hülâsa-i Tarihiyesi. Türk Kütüphaneciler Derneği Bülteni, $\quad 17 \quad$ (1): $15-23 . \quad$ Erişim adresi: http://www.tk.org.tr/index.php/TK/article/view/1817/1797

Karatay, F.E. (1968). Hayatımdan Parçalar. Türk Kütüphaneciler Derneği Bülteni, 17 (2), 73-74. Erişim adresi: http://www.tk.org.tr/index.php/TK/article/view/1835/1815

Karatepe, T.Ç. (2013). "Yıldız Sarayı Kütüphanesi", TDV İslam Ansiklopedisi, 43, 544-545.

Ötüken, A. (1957). Türkiyede Kütüphanecilik Öğretiminin Tarihçesi. Türk Kütüphaneciler Derneği Bülteni, 6 (1-2), 1-35. Erişim adresi: http://tk.org.tr/index.php/TK/article/view/2110/2078

Sahaflar, bibliyomanlar ve yuppiler:"90"1n son müzayedesinde 238 kitap, 70 milyon liraya satıldı. (t.y.). [Gazete Kupürü]. Taha Toros Arşivi (Envanter No: 001505409006), İstanbul Şehir Üniversitesi e-Arşiv Sistemi. Erişim adresi: http://earsiv.sehir.edu.tr:8080/xmlui/bitstream/handle/11498/6502/001505409006.pdf?sequen $\mathrm{e}=1 \&$ isAllowed $=\mathrm{y}$

Stummvoll, J. (1962). Türk Kütüphaneleri ve Türk Kütüphaneciliği. (M. Derer, Çev.). Türk Kütüphaneciler Derneği Bülteni, 11 (1-2), 44-47. Erişim adresi: http://tk.org.tr/index.php/TK/article/view/2045/2014

Subaşığlu, F. ve Tamdoğan, O. G. (2014). Ankara Üniversitesi Kütüphanecilik Bölümü'nün Kuruluş Öyküsü, Türk Kütüphaneciliği, 28 (4), 583-621. Erişim adresi: http://tk.org.tr/index.php/TK/article/view/2491/2500

Şehsuvaroğlu, B. N. (1975). Birinci Ölüm Yıldönümü Nedeniyle: Nurettin Kalkandelen 1902-1974. Türk Kütüphaneciler Derneği Bülteni, 24 (4), 331-333. Erişim Adresi: http://tk.org.tr/index.php/TK/article/view/2344/2308

Şenalp, L. (2001). İstanbul Üniversitesi Merkez Kütüphanesi: Başlangıcından Günümüze. Ankara: Türk Kütüphaneciler Derneği.

TK Yayın Kurulu (1952). Türk Kütüphaneciliğine Hizmet Edenler: 2 H. Fehmi Edhem Karatay. Türk Kütüphaneciler Derneği Bülteni, 1 (1), 69-70. Erişim adresi: http://www.tk.org.tr/index.php/TK/article/view/2307/2272

TK Yayın Kurulu (1968). Fehmi Ethem Karatay ve Aziz Berker'i Kaybettik. Türk Kütüphaneciler $\begin{array}{llllll}\text { Derneği Bülteni, } & 17 & \text { (1), } & 61 . & \text { Erişim } & \text { adresi: }\end{array}$ http://www.tk.org.tr/index.php/TK/article/view/1833/1813 
Tüfekçibaşı, A. (1997). İstanbul Üniversitesi Merkez Kütüphanesinin Yararlandırma Hizmetlerinde Bağlı Birimlerle İlişkileri (yayımlanmamış yüksek lisans tezi). İstanbul Üniversitesi Sosyal Bilimler Enstitüsü, İstanbul.

Türk Kütüphaneciliğinin öncülerinden Fehmi Ethem Karatay ve Aziz Berker için, ebediyete göçüşlerinin 15. yıldönümü dolayısıyla düzenlenen anma toplantısı. (1983). [Ankara]: Türk Kütüphaneciler Derneği.

Üstün, A. (1977). Üniversite Kütüphaneleri. Türk Kütüphaneciler Derneği Bülteni, 26 (4), 229-235. Erişim adresi: http://www.tk.org.tr/index.php/TK/article/view/1772/1754

XXXI Kütüphane Haftası Kutlama Programı. (1995). [Broşür]. Taha Toros Arşivi (Envanter No: 001610201016), İstanbul Şehir Üniversitesi e-Arşiv Sistemi. Erişim adresi: http://earsiv.sehir.edu.tr:8080/xmlui/bitstream/handle/11498/13786/001610201016.pdf?seque ce $=1 \&$ is Allowed $=y$

Yazıbakan, Y. (2019). Devlet Salnâmeleri'ne Göre 1925-1928 Yılları Arasında Türkiye'de Eğitim (yayımlanmamış yüksek lisans tezi). Kastamonu Üniversitesi Sosyal Bilimler Enstitüsü, Kastamonu. 